JOURNAL OF MARINE RESEARCH AND TECHNOLOGY

journal homepage: https://ojs.unud.ac.id/index.php/JMRT ISSN: 2621-0096 (electronic); 2621-0088 (print)

\title{
Monitoring Perubahan Penggunaan Lahan Pesisir Di Kecamatan Batu Layar, Kabupaten Lombok Barat Pada Tahun 2002 dan 2019
}

\author{
Mark Johannes Wiggers ${ }^{\mathrm{a}}$, I Wayan Nuarsa ${ }^{\mathrm{a}^{*}}$, and I Dewa Nyoman Nurweda Putra
}

${ }^{a}$ Program Studi Ilmu Kelautan, Fakultas Kelautan dan Perikanan, Universitas Udayana, Bali, Indonesia

* Corresponding author email: nuarsa@unud.ac.id

\section{ARTICLE INFO}

Article history:

Received: June $10^{\text {th }} 2020$

Received in revised form: July $27^{\text {th }} 2020$

Accepted: August $6^{\text {th }} 2020$

Available online: August $31^{\text {th }} 2020$

Keywords:

Coastal area

Remote Sensing

Land Use

Landsat

\section{ABSTRACT}

The coastal zone is a unique region because the coastal area is a meeting place of land and sea. Coastal areas are vulnerable to various human activities that can affect the terrestrial and marine environment both directly and indirectly. This can result in changes in land use, especially in coastal areas. Rapid changes in land use in coastal areas due to the development of tourist areas and the high level of erosion and abrasion that occurs causes the need for planned, comprehensive and sustainable land management planning and regional development. the purpose of this study was to determine land use, land use changes and the level of accuracy of landsat imagery in coastal areas of Batu Layar District, West Lombok Regency. This study uses the Quantum GIS software to analize Landsat satellite imagery data in 2002 and 2019. The results showed that the land use change during of 17 years (2002 - 2019), namely the residential and building classes increased by 237.69 ha and while the bush class , forests, plantations, rice fields, open land and waters respectively decreased by 71.91 ha, 61.2 ha, 46.44 ha, 32.4 ha, 20.79 and 5.04 ha respectively. The Overall Accuracy of this study was $90 \%$

2020 JMRT. All right reserved

\section{Pendahuluan}

Wilayah pesisir atau coastal zone adalah wilayah yang "unik" karena wilayah pesisir merupakan tempat bertemunya daratan dan lautan (Asyiawati, 2010). Wilayah pesisir rentan terhadap berbagai aktivitas manusia yang dapat mempengaruhi lingkungan daratan dan perairan baik secara langsung maupun tidak langsung (Chua, 2006). Kegiatan di wilayah pesisir jika tidak dikelola dengan baik dapat menimbulkan permasalahan penggunaan lahan (Dahuri et al, 2013). Lebih lanjut dijelaskan bahwa kawasan pesisir yang dimanfaatkan akan berdampak terhadap daya dukung ekosistem pesisir dan lautan seperti terjadinya pencemaran, penurunan kondisi fisik habitat, abrasi, dan sedimentasi terutama wilayah pesisir dengan penduduk padat dan tingkat pembangunan yang tinggi.

Pertumbuhan jumlah penduduk akan diikuti oleh meningkatnya kebutuhan lahan untuk pemukiman. Menurut Damai (2003), 43\% penduduk dunia tinggal di wilayah pesisir. Hal ini menyebabkan terjadinya konversi lahan dari lahan bervegetasi menjadi pemukiman dan bangunan. Kondisi ini juga terjadi di wilayah pesisir Kecamatan Batu Layar Kabupaten Lombok Barat Provinsi Nusa Tenggara Barat, yang memiliki luas wilayah $34,11 \mathrm{~km}^{2}$ dengan kepadatan 14,540 jiwa/km² (BPS, 2019).

Kawasan Kecamatan Batu Layar ini menjadi salah satu andalan wisata di Pulau Lombok. Perkembangan sektor pariwisata yang pesat dapat meningkatkan konversi dari lahan bervegetasi menjadi fasilitas penunjang wisata dan pemukiman. Oleh sebab itu perlu perencanaan penggunaan lahan dan pengembangan wilayah yang terencana dan terintegrasi, agar tercipta model perencanaan tata ruang yang komprehensif dan berkelanjutan (Herdiatma et al., 2014). Pengelolaan data perubahan penggunaan lahan hingga saat ini masih menggunakan metode konvensional yang memerlukan waktu yang cukup lama untuk mengumpulkan data penggunaan lahan serta membutuhkan sumber daya yang cukup besar dalam "pelaksanaannya" oleh karena itu dibutuhkannya informasi yang mudah diakses dan yang terbaru, dalam hal ini teknik penginderaan jauh (remote sensing) dapat menjawab hal tersebut. Penginderaan jauh dapat dimanfaatakan sebagai salah satu sumber data lingkungan abiotik (sumberdaya alam) dan lingkungan biotik (flora dan fauna serta lingkungan budaya dan bentuk penggunaan lahan. (Hartono, 2010).

Teknologi penginderaan jauh telah mengalami perkembangan dan memiliki resolusi yang berbeda-beda pada setiap salit yang telah diluncurkan. Pada pemetaan perubahan penggunaan lahan dilakukan dengan menggunakan citra satelit landsat. Satelit landsat merupakan salah satu satelit yang dipelopori oleh gabungan USGS (United States Geological Survey) dan NASA Amerika Serikat yang dipimpin oleh perusahaan Pengamatan Bumi (Earth Observatory EO) yang mewakili sistem satelit terlama di dunia, Citra satelit yang dipergunakan yaitu landsat 8 OLI, TIRS dan landsat 7 ETM+. Citra landsat 8 memiliki sensor Operational Land Imager (OLI), Thermal Infrared Sensor (TIRS) memiliki 11 band dengan resolusi $30 \mathrm{~m}$ dan untuk pankromatik mencapai resolusi $15 \mathrm{~m}$ dan untuk landsat 8 nilai $\mathrm{DN}$ memiliki nilai interval yang lebih Panjang yaitu $0-4096$ atau tiap piksel memiliki kuantifikasi 12 bit (USGS, 2019) walaupun resolusi 
dari data ini tidak setinggi citra berbayar seperti Ikonos, Geo eye atau Quick Bird namun resolusi $30 \mathrm{~m}$ dengan piksel 12 bit dari landsat ini memberikan begitu banyak informasi berharga bagi para pengguna dan produk citra ini bersifat time series tanpa striping dan biasa dipergunakan untuk melakukan penelitian pemetaan penggunaan lahan. (Herdiatma et al., 2014).

Penelitian ini bertujuan memetakan penggunaan lahan tahun 2002 dan 2019 di Kecamatan Batu Layar Lombok Barat, menganalisis perubahan yang terjadi, dan menguji tingkat akurasi Citra Landsat 8 OLI dalam memetakan penggunaan lahan.

\section{Metode Penelitian}

\subsection{Waktu Lokasi Penelitian}

Lokasi penelitian ini berada di kawasan wilayah pesisir dengan ketinggian antara 0 - 20 meter di atas permukaan laut, di Kecamatan Batu Layar Lombok Barat 08030'27' LS dan $116^{0} 04^{\prime} 03$ ” BT Pengambilan data lapangan pada tanggal 26 bulan Desember 2019. Pengolahan data dan analisis data dilaksanakan pada bulan Januari 2020 di Laboratorium Remote Sensing, Fakultas Kelautan dan Perikanan, Universitas Udayana. Lokasi pengambilan data lapangan dapat dilihat pada Gambar 1.

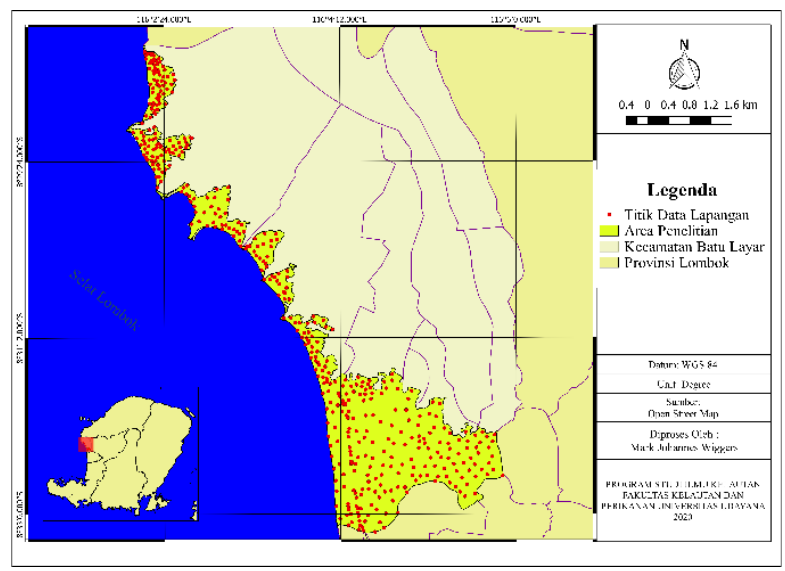

Gambar 1. Peta Lokasi Penelitian di Kecamatan Batu Layar

\subsection{Alat dan Bahan}

Alat yang digunakan pada penelitian ini yaitu laptop, Software Quantum GIS, Microsoft Office, GPS Garmin, Kamera Digital, Buku Catatan dan Alat Tulis. Sementara itu bahan digunakan meliputi Citra Landsat 7 ETM+ 2002, Citra Landsat 8 OLI, TIRS 2019 yang didownload dari https://earthexplorer.usgs.gov/ dan Peta Topografi dari DEM Nasional tahun 2018 yang didownload dari http://tides.big.go.id/DEMNAS/ dan Peta Rupabumi Kecamatan Batu Layar..

\subsection{Metode Peneltiian}

Prosedur pengolahan citra pada penelitian ini mengacu pada prosedur pengolahan citra oleh LAPAN (2014). Tahapan dalam pengolahan citra adalah : 1) Pra Pengolahan Citra; 2) Pengolahan Citra; 3) Ground Check; 4) Uji Ketelitian (Gambar 2). Keempat tahapan tersebut dilakukan untuk memperoleh hasil peta perubahan penggunaan lahan pesisir dari Citra Landsat. Diagram alir langkah kerja dapat dilihat pada Gambar 2.

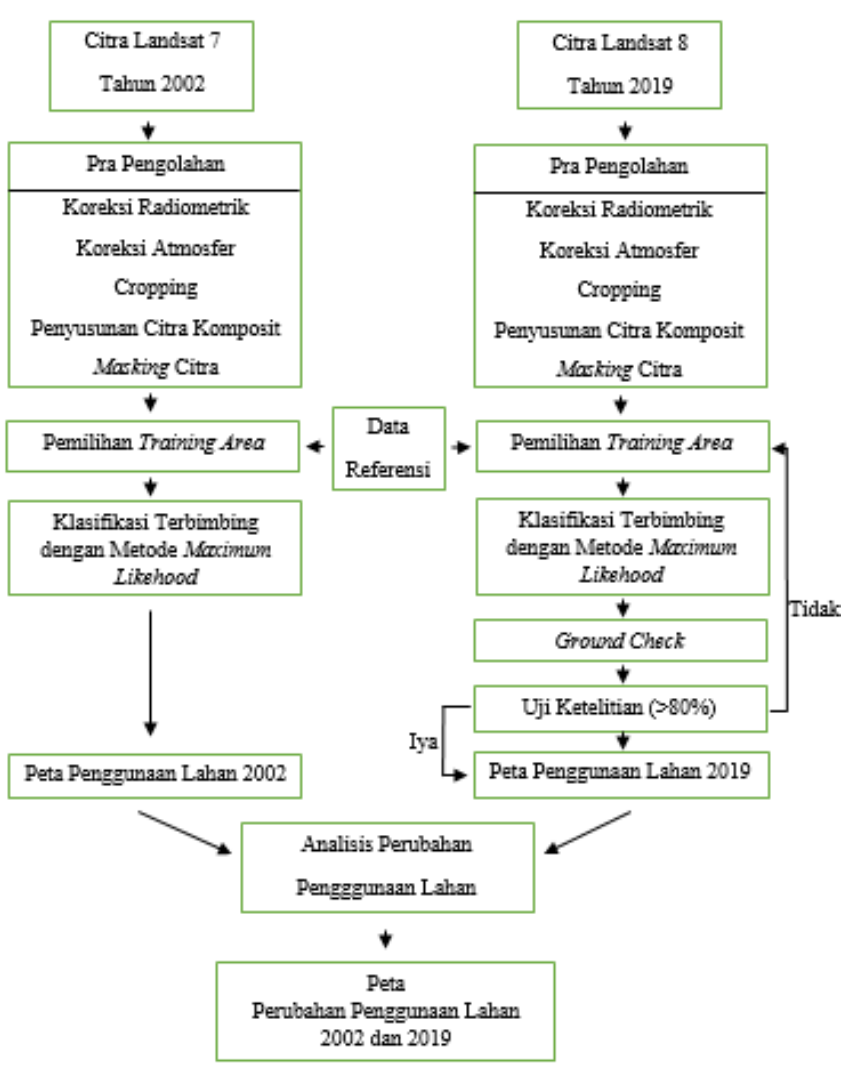

Gambar 2. Diagram Alir Penelitian

\subsubsection{Pra Pengolahan Citra}

Pra pengolahan citra diawali dengan koreksi atmosfer. Proses ini bertujuan untuk memperbaiki suatu nilai piksel pada citra dari gangguan atmosfer. Efek atmosfer mengakibatkan nilai pantulan objek di permukaan bumi yang terekam oleh sensor tidak sesuai dengan nilai aslinya. Nilai digital citra menjadi lebih besar karena adanya hamburan atau nilai akan menjadi kecil karena adanya serapan. Pada penelitian ini menggunakan metode Dark Object Substraction (DOS). Adapun persamaan tersebut dapat dilihat pada Persamaan (1)

Atmospherically corrected radiance $=L i-L s i$

Dimana Li adalah pixel dari radiance band $I$ dan $L s i$ adalah nilai rata - rata cahaya untuk kolom air dalam band $i$.

Citra hasil koreksi atmosfer selanjutnya dilakukan pemotongan citra atau cropping. Pemotongan citra ini bertujuan untuk membatasi daerah penelitian sehingga memudahkan analisis. Pemotongan citra dapat mengurangi kapasitas memori file sehingga memudahkan dalam pengolahan citra serta memfokuskan perhatian pada daerah yang akan dikaji. Proses selanjutnya adalah pembuat citra komposit. Dalam penelitian ini menggunakan komposit warna asli (true color composite). Pada komposit warna asli menggunakan kombinasi warna RGB 432, yaitu band 4, band 3 dan band 2 masing-masing diberikan warna dasar merah, hijau, dan biru. Kemudian dilanjutkan dengan masking citra. Proses masking citra dilakukan dengan menggunakan data shapefile daerah penelitian. Dengan ketinggian 0 - 20 meter di atas permukaan laut. 


\subsubsection{Pengolahan Citra}

Pengolahan citra diawali dengan pemilihan training area karena menggunakan metode supervised classification. Proses ini bertujuan untuk mengelompokkan pixel-pixel menjadi kelompok piksel yang mempunyai kemiripan nilai spectral. Pemilihan training area dilakukan dengan turun langsung ke lapangan mencari koordinat setiap kelas pengunaan lahan untuk tahun 2019. Kelas penggunaan lahan terdiri dari sawah, hutan, pemukiman dan air. Setelah semua kelas penggunaan lahan ditentukan training areanya. Dilanjutkan dengan dilanjutkan proses dengan klasifikasi citra. Algoritma klasifikasi citra yang digunakan adalah Maximum likelihood. Maximum Likelihood Method ini paling banyak digunakan dalam klasifikasi terbimbing. Metode ini akan mengkelaskan nilai piksel yang belum diketahui identitasnya berdasarkan vektor rata-rata serta nilai varian dan kovarian dari setiap training area. Piksel dimasukkan menjadi salah satu kelas yang probabilitas (peluang) paling tinggi terhadap kelas tertentu dalam sampel piksel (Setiono, 2006).

\subsubsection{Pengecekan Lapangan (Ground Check)}

Pemeriksaan lapangan dilakukan untuk memperoleh informasi penggunaan lahan di seluruh daerah penelitian sebagai informasi dalam pembuatan training area dan basis data dalam uji ketelitian. Pengecekan lapangan dilakukan dengan cara menelusuri lokasi pengamatan yang telah ditentukan dengan mengambil titik koordinat dengan metode purposive sampling dengan mempertimbangkan keragaman atau variabilitas kelas penggunaan lahan (Schreuder et al., 2004). Jumlah titik sampel yang diambil pada penelitian adalah 450 titik. Sebanyak 70\% (315 titik) digunakan sebagai informasi penggunaan lahan dalam pengambilan training area untuk klasifikasi citra dan 30\% (135 titik) untuk uji akurasi.

\subsection{Analisis Ketelitian Data}

Uji akurasi dilakukan untuk mengetahui ketelitian dari hasil klasifikasi citra. Analisis ini menggunakan metode matriks kesalahan (Confusion Matrix). Confussion Matrix merupakan matriks yang disusun untuk menentukan nilai akurasi dari akurasi pembuat (Producers Accuracy), akurasi pengguna (User Accuracy), dan akurasi keseluruhan (Overall Accuracy). Matriks ini juga menghitung error atas kesalahan dari hasil klasifikasi citra yaitu kesalahan omisi (Omission Error) dan kesalahan komisi (Commission Error). Persamaan akurasi tersebut adalah sebagai berikut :

User's Accuracy $=\frac{\mathrm{Xii}}{X_{+i}} \times 100 \%$

Producer's Accuracy $=\frac{\mathrm{Xii}}{X_{+i}} \times 100 \%$

Overall Accuracy $=\frac{\sum_{i=1}^{r} \mathrm{Xii}}{N} \times 100$

Omission error $=100 \%-$ Producer accuracy

Comission error $=100 \%-$ User accuracy

Dimana $\mathrm{N}=$ Jumlah semua piksel yang digunakan untuk pengamatan; $r=$ Jumlah baris atau lajur pada matriks kesalahan (jumlah kelas); Xii = Nilai diagonal dari matrik baris ke-i dan kolom ke-i; $\mathrm{X}+\mathrm{I}=$ Jumlah piksel dalam kolom ke-i; $\mathrm{Xi}+=$ Jumlah piksel dalam baris ke-i.

Tingkat ketelitian hasil klasifikasi penggunaan lahan dengan menggunakan data penginderaan jauh yang sudah ditetapkan oleh Badan Survei Geologi Amerika Serikat (USGS) tidak kurang dari $85 \%$. Bila tingkat ketelitian hasil klasifikasi kurang dari $85 \%$ akan dilakukan klasifikasi ulang dengan memperbaiki training area

\section{Hasil Dan Pembahasan}

\subsection{Pembuatan Training Area}

Dalam klasifikasi penggunaan lahan dengan metode terbimbing (supervised classification), pembuatan training area merupakan tahap awal dalam proses klasifikasi. Kecermatan dalam pengambilan training area akan menentukan ketelitian klasifikasi. Hal ini disebabkan karena nilai digital citra pada training area akan digunakan sebagai basis data dalam proses klasifikasi terbimbing. Berdasarkan hasil pengamatan pada citra komposit RGB 432, 315 titik training area yang digunakan terdapat tujuh kelas penggunaan lahan adalah hutan, semak, sawah, perkebunan, lahan terbuka, pemukiman dan bangunan, dan perairan.

Tingkat akurasi hasil klasifikasi ditentukan oleh ketelitian dalam pengambilan training area. Pola spektral dan berbagai informasi statistik seperti nilai minimal, maksimal, rata-rata dan standar deviasi dibutuhkan untuk menghasilkan klasifikasi yang baik. Pola Spektral yang digunakan sebagai training area dalam proses klasifikasi dapat dilihat pada Gambar 3.

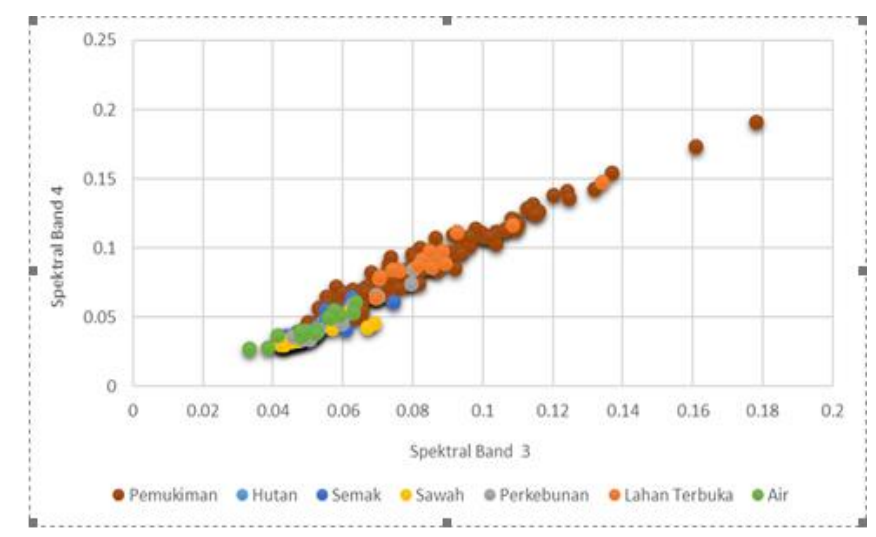

Gambar 3. Pola spektral pada ruang spektral Band 4 (merah) dan Band 3 (green)

Pada Gambar 3 terlihat pola spektral kelas pemukiman menempati ruang yang terpisah dari kelas spektral yang lainnya, ini berarti training area pada kelas-kelas tersebut akan terkelaskan dengan baik, sementara itu untuk kelas hutan, semak, sawah, lahan terbuka dan air terlihat menumpuk. Ini berarti kelas-kelas tersebut agak susah dibedakan dengan baik.

\subsection{Klasifikasi Penggunaan Lahan}

Berdasarkan training area yang dibuat dan pengamatan lapangan yang dilakukan, klasifikasi penggunaan lahan pada Citra Landsat menggunakan metode Maksimum Likelihood pada penelitian ini. Diperoleh 7 kelas penggunaan lahan, yaitu hutan, semak, sawah, perkebunan, lahan terbuka, pemukiman dan bangunan, dan perairan. Klasifikasi kelas penggunaan lahan dapat dilihat pada Tabel 1. Sementara itu, peta distribusi penggunaan lahan daerah penelitian tahun 2002 dan 2019 disajikan pada Gambar 4. 
Tabel 1. Kelas penggunaan lahan

\begin{tabular}{|c|c|c|c|}
\hline No. & $\begin{array}{c}\text { Jenis } \\
\text { Penggunaan } \\
\text { Lahan }\end{array}$ & Warna & Keterangan \\
\hline 1 & Hutan & & $\begin{array}{l}\text { Vegetasi berupa pepohonan } \\
\text { teratur }\end{array}$ \\
\hline 2 & Semak & & $\begin{array}{l}\text { Vegetasi berupa pohon yang } \\
\text { tidak teratur }\end{array}$ \\
\hline 3 & Sawah & & Vegetasi lahan basah \\
\hline 4 & Perkebunan & & Vegetasi campuran \\
\hline 5 & $\begin{array}{l}\text { Lahan } \\
\text { Terbuka }\end{array}$ & & Pasir, lahan, lapangan \\
\hline 6 & $\begin{array}{l}\text { Pemukiman } \\
\text { dan } \\
\text { bangunan }\end{array}$ & & $\begin{array}{l}\text { Bangunan } \\
\text { (rumah,hotel,jalan,masjid) }\end{array}$ \\
\hline 7 & Perairan & & Air laut, sungai \\
\hline
\end{tabular}

Penggunaan lahan terluas di daerah penelitian pada tahun 2002 adalah pemukiman dan bangunan yaitu 328.05 ha (36\%), diikuti sawah 158.58 ha (17\%), hutan 136.35 ha (15\%), semak 102.96 ha $(11 \%)$, perkebunan 88.38 ha $(10 \%)$, lahan terbuka 71.82 ha $(8 \%)$ dan penggunaan dengan luas lahan paling kecil adalah perairan yaitu 20,7 ha (2\%) (Tabel 2).

Tabel 2. Penggunaan lahan daerah penelitian tahun 2002

\begin{tabular}{|c|c|c|}
\hline Nama kelas & Luas (ha) & Persentasi (\%) \\
\hline Hutan & 136.35 & $15 \%$ \\
\hline Semak & 102.96 & $11 \%$ \\
\hline Sawah & 158.58 & $18 \%$ \\
\hline Perkebunan & 88.38 & $10 \%$ \\
\hline Lahan Terbuka & 71.82 & $8 \%$ \\
\hline $\begin{array}{c}\text { Pemukiman dan } \\
\text { bangunan }\end{array}$ & 328.05 & $36 \%$ \\
\hline Perairan & 20.7 & $2 \%$ \\
\hline Total & 906.84 & $100 \%$ \\
\hline
\end{tabular}

Pada peta penggunaan lahan daerah penelitian tahun 2019, pemukiman dan bangunan mengalami kenaikan dan masih menjadi penggunaan terluas yang mencapai angka 565.83 ha $(62 \%)$, diikutin oleh sawah 126.18 ha (14\%), hutan 75.42 ha $(8 \%)$, semak 31.05 ha (3\%), perkebunan 41.94 ha (5\%), lahan terbuka 51.12 ha $(6 \%)$ dan penggunaan lahan paling kecil adalah perairan yaitu 15.66 ha $(2 \%)$. (Tabel 4). Dari Tabel 2 dan Tabel 3 dapat dilihat bahwa penggunaan lahan pemukiman dan bangunan dan perairan merupakan penggunaan lahan dengan luas tertinggi dan terendah pada tahun 2002 dan 2019.

Berdasarkan data dari Badan Pusat Statistik Kabupaten Lombok Barat (2019) yang mengeluarkan data pada tahun 2017 pada pemukiman dan bangunan di daerah Kecamatan Batu Layar seluas 951.31 ha untuk sawah 245.51 ha, perkebunan 595.53 ha, lahan terbuka 179.871 ha dapat dilihat perbedaan antara data hasil penelitian dengan data BPS (2019) hal ini dikarenakan hasil penelitian hanya di fokuskan pada wilayah pesisir dengan ketinggian 0-20 mdpl dan untuk data dari BPS (2019) yang dikeluarkan pada tahun 2017 mencakup keseluruhan wilayah Kecamatan Batu Layar.

Tabel 3. Penggunaan lahan daerah penelitian tahun 2019

\begin{tabular}{|c|c|c|}
\hline Nama kelas & Luas (ha) & Persentasi (\%) \\
\hline Hutan & 75.61 & $8 \%$ \\
\hline Semak & 31.05 & $3 \%$ \\
\hline Sawah & 126.18 & $14 \%$ \\
\hline Perkebunan & 41.94 & $5 \%$ \\
\hline Lahan Terbuka & 51.12 & $6 \%$ \\
\hline $\begin{array}{c}\text { Pemukiman dan } \\
\text { bangunan }\end{array}$ & 565.74 & $62 \%$ \\
\hline Perairan & 15.66 & $2 \%$ \\
\hline Total & 906.84 & $100 \%$ \\
\hline
\end{tabular}

\subsection{Perubahan Penggunaan Lahan}

Analisis perubahan penggunaan lahan pesisir di daerah peneltiian selama 17 tahun $(2002$ - 2019) dapat dilihat pada Tabel 5. Dari Tabel tersebut dapat dilihat bahwa penggunaan lahan yang mengalami peningkatan hanyalah pemukiman dan bangunan. Sementara hutan, semak, sawah, perkebunan, lahan terbuka, dan perairan mengalami penurunan. Luas perubahan
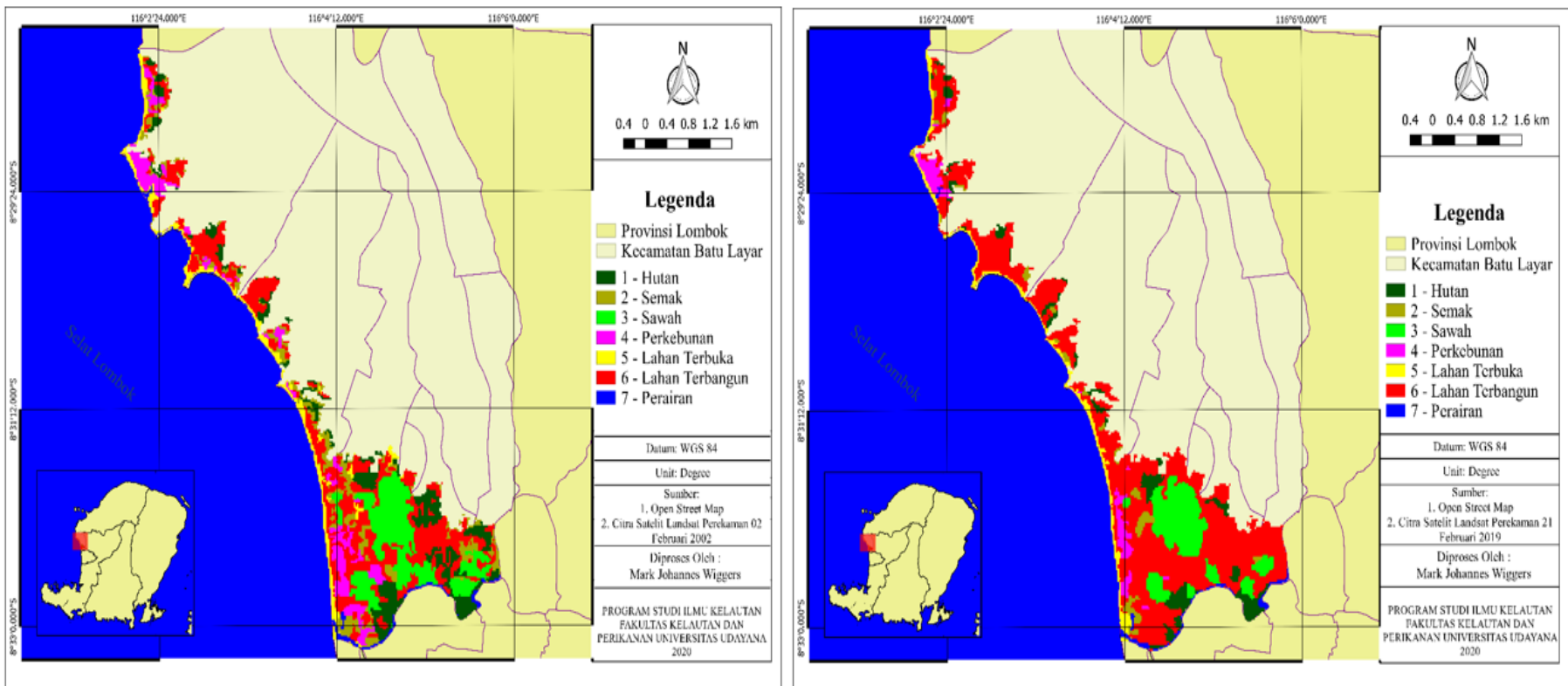

Gambar 4. Peta Penggunaan Lahan Daerah Penelitian Tahun 2002 (Gambar kiri) dan 2019 (Gambar kanan) 
lahan pada setiap kelas pada tahun 2002 dan 2019 dapat dilihat pada Tabel 4. Sementara itu, bentuk konversi penggunaan lahan di tahun 2002 dan 2019 disajikan pada Tabel 5.

Tabel 4. Luas perubahan lahan tahun 2002 dan 2019

\begin{tabular}{|c|c|c|c|}
\hline Nama Kelas & Tahun 2002 & Tahun 2019 & $\begin{array}{c}\text { Luas } \\
\text { Perubahan } \\
\text { (ha) }\end{array}$ \\
\hline Hutan & 136.5 & 75.42 & -60.93 \\
\hline Semak & 102.96 & 31.05 & -71.91 \\
\hline Sawah & 158.58 & 126.18 & -32.4 \\
\hline Perkebunan & 88.38 & 41.94 & -46.44 \\
\hline Lahan Terbuka & 71.91 & 51.12 & -20.79 \\
\hline $\begin{array}{c}\text { Pemukiman } \\
\text { dan Bangunan }\end{array}$ & 328.32 & 565.83 & 237.51 \\
\hline Perairan & 20.7 & 15.66 & -5.04 \\
\hline Total & 907.2 & 907.2 & \\
\hline
\end{tabular}

Perubahan luas penggunaan lahan di wilayah pesisir di daerah penelitian yang mengalami kenaikan signifikan adalah pemukiman dan bangunan, yaitu seluas 237.51 ha. Penggunaan lahan di tahun 2002 yang paling banyak mengalami perubahan menjadi pemukiman dan bangunan di tahun 2019 adalah penggunan lahan semak seluas 78.48 ha dan hutan seluas 74.88 ha dapat dilihat pada Tabel 5. Hal ini sesuai dengan pernyataan dari Darmawan (2016), bahwa daerah Kecamatan Batu Layar ini merupakan daerah objek wisata yang berkembang pesat. Berbagai hal yang mendorong perkembangan daerah ini adalah potensi sumberdaya yang dimiliki seperti terumbu karang, wisata pantai potensi penangkapan ikan dan pengolahan hasil laut. Dukungan pemerintah dengan membentuk PT Pengembangan Pariwisata Lombok atau Lombok Tourism Development Corporation (LTDC) juga merupakan faktor penting dalam pengembangan Kecamatan Batu Layar sebagai daerah destinasi wisata. Hasil observasi lapangan menunjukkan banyaknya bangunan dan fasilitas penunjang pariwisata didekat pantai.

Menurut Darmawan (2016) sebagian besar penduduk Kecamatan Batu layar merupakan petani kebun yang memiliki daerah yang cukup luas dengan area kebun kelapa dan persawahan. Perkembangan daerah wisata di daerah penelitian membawa dampak terhadap konversi lahan bervegetasi menjadi pemukiman dan bangunan. Hal ini dapat dilihat dari penurunan lahan dengan cakupan wilayah yang luas yaitu semak seluas 71.91 ha ini terjadi karena perubahan penggunaannya dari semak menjadi penggunaan lahan lainnya, perubahan lahan dari semak paling banyak berubah menjadi penggunaan lahan pemukiman dan bangunan seluas 78.48 ha. Konversi penggunaan lahan pada lahan terbuka mengalami penurunan seluas 20.79 ha ini terjadi karena perubahan penggunaan dari lahan terbuka paling banyak berubah menjadi pemukiman dan bangunan seluas 26.28 ha dan pada daerah perairan mengalami penururan 5.04 ha diakibatkan karena banyakanya perubahan lahan pada lahan terbuka seluas 6.93 ha.

Perubahan penggunaan lahan yang cepat di daerah penelitian akibat adanya perkembangan kawasan wisata menyebabkan perlunya perencanaan pengelolaan lahan dan pengembangan wilayah yang terencana, komprehensif, dan berkesinambungan. Hasil pemetaan penggunaan lahan dan perubahannya dalam kurun waktu 17 tahun $(2002$ - 2019) di daerah penelitian dapat digunakan sebagai salah satu data inputan dalam proses perencanaan dan pengelolaan tata guna lahan.

\subsection{Analisis Ketelitian Data}

Hasil klasifikasi penggunaan lahan menggunakan Citra Landsat 8 OLI perlu dilakukan uji ketelitian menggunakan matrik kesalahan (confusion matrix). Hal ini dilakukan untuk melihat tingkat akurasi yang dihasilkan dalam proses klasifikasi. Proses uji ketelitian dilakukan dengan membandingkan data hasil klasifikasi dengan citra satelit

\section{Tabel 5.}

Konversi penggunaan lahan tahun 2002 dan 2019

\begin{tabular}{|c|c|c|c|c|c|c|c|c|c|}
\hline \multirow{2}{*}{\multicolumn{2}{|c|}{ Nama Kelas }} & \multicolumn{8}{|c|}{ Tahun 2019** } \\
\hline & & \multicolumn{8}{|c|}{ Luas (ha) } \\
\hline & & $\mathrm{HU}$ & SE & SA & PE & LT & PB & $\mathrm{P}$ & Total \\
\hline \multirow{8}{*}{$\begin{array}{l}\text { Tahun } \\
2002 * \\
\text { Luas } \\
\text { (ha) }\end{array}$} & $\mathrm{HU}$ & 53.82 & 1.98 & 3.33 & 0.36 & 0.18 & 74.88 & 1.8 & 136.35 \\
\hline & SE & 4.05 & 11.79 & 1.89 & 3.69 & 2.25 & 78.48 & 0.81 & 102.96 \\
\hline & SA & 3.51 & 0.18 & 100.08 & 1.26 & - & 53.28 & 0.27 & 158.58 \\
\hline & PE & 2.52 & 4.05 & 1.08 & 26.64 & 0.99 & 52.56 & 0.54 & 88.38 \\
\hline & LT & 1.17 & 2.52 & - & 2.25 & 37.26 & 26.28 & 2.34 & 71.82 \\
\hline & PB & 8.46 & 10.26 & 19.71 & 7.56 & 3.51 & 278.55 & - & 328.05 \\
\hline & $\mathrm{P}$ & 1.62 & 0.27 & 0.09 & 0.18 & 6.93 & 1.71 & 9.9 & 20.7 \\
\hline & Total & 75.15 & 31.05 & 126.18 & 41.94 & 51.12 & 565.74 & 15.66 & 906.84 \\
\hline
\end{tabular}

Keterangan : *dibaca horizontal dan **dibaca vertikal

Keterangan: Hutan (HU), Semak (SE), Sawah (SA), Perkebunan (PA), Lahan Terbuka (LT), Pemukiman dan bangunan (PB) dan Perairan $(\mathrm{P})$. 
Tabel 6.

Matriks kesalahan hasil interpretasi dan klasifikasi penggunaan lahan tahun 2019

\begin{tabular}{|c|c|c|c|c|c|c|c|c|c|c|}
\hline \multirow{2}{*}{$\begin{array}{c}\text { Hasil } \\
\text { Klasifikasi }\end{array}$} & \multicolumn{7}{|c|}{ Data Survei Lapangan } & \multirow{2}{*}{ Total } & \multirow{2}{*}{$\begin{array}{l}\text { PA } \\
(\%)\end{array}$} & \multirow{2}{*}{$\begin{array}{l}\mathrm{CE} \\
(\%)\end{array}$} \\
\hline & HU & $\mathrm{SE}$ & SA & $\mathrm{PE}$ & LT & PB & $\mathrm{P}$ & & & \\
\hline $\mathrm{HU}$ & 13 & 0 & 0 & 0 & 0 & 2 & 0 & 15 & $68 \%$ & $32 \%$ \\
\hline SE & 0 & 10 & 0 & 1 & 1 & 3 & 0 & 15 & $71 \%$ & $29 \%$ \\
\hline SA & 0 & 0 & 15 & 0 & 0 & 0 & 0 & 15 & $100 \%$ & $0 \%$ \\
\hline $\mathrm{PE}$ & 0 & 1 & 0 & 12 & 0 & 2 & 0 & 15 & $71 \%$ & $29 \%$ \\
\hline LT & 0 & 0 & 0 & 0 & 15 & 0 & 0 & 15 & $66 \%$ & $32 \%$ \\
\hline PB & 6 & 3 & 0 & 3 & 4 & 206 & 1 & 225 & $97 \%$ & $3 \%$ \\
\hline $\mathrm{P}$ & 0 & 0 & 0 & 1 & 2 & 0 & 11 & 15 & $92 \%$ & $8 \%$ \\
\hline Total & 19 & 14 & 15 & 17 & 22 & 213 & 12 & 315 & & \\
\hline UA (\%) & $87 \%$ & $67 \%$ & $100 \%$ & $80 \%$ & $100 \%$ & $92 \%$ & $73 \%$ & & $\mathrm{OA}(\%)$ & $90 \%$ \\
\hline OE (\%) & $13 \%$ & $33 \%$ & $0 \%$ & $20 \%$ & $0 \%$ & $8 \%$ & $27 \%$ & & & \\
\hline
\end{tabular}

Keterangan: Hutan (HU), Semak (SE), Sawah (SA), Perkebunan (PA), Lahan Terbuka (LT), Pemukiman dan bangunan (PB) dan Perairan $(\mathrm{P})$.

terhadap kelas penggunaan lahan yang sebenarnya di lapangan. Hal ini penting dilakukan untuk mengetahui layak tidaknya data hasil klasifikasi ini digunakan sebagai inputan untuk proses analisis spasial yang lain. Hasil dari uji akurasi ini dinyatakan dengan nilai Users Accuracy, Producers Accuracy, Overall Accuracy, Omission Error, dan Comission Error. Jumlah titik sampel yang diambil secara purposive sampling adalah 135 titik.

Producers accuracy menggambarkan ketepatan jangkuan daerah dari training area yang diambil untuk mewakili kelas tertentu. Sementara Users Accuracy menggambarkan ketepatan antara training area yang sudah diberi kelas tertentu dengan kelas yang ada di lapangan. Jika jangkauan daerah training area sempit atau keseluruhan nilai spektral dari suatu kelas tidak diambil maka akan menimbulkan nilai kesalahan omisi ini berarti sejumlah piksel yang semestinya akan termasuk ke dalam kelas tertentu tidak dapat dijangkau oleh nilai spektral yang dipakai sebagai training area. Sebaliknya jika jangkauan training area melebar maka akan mengeluarkan nilai kesalahan komisi, karena piksel yang semestinya tidak termasuk dalam suatu kelas tersebut maka akan menjadi kelas tersebut. (Nuarsa, 1998) Matriks kesalahan hasil klasifikasi penggunaan lahan tahun 2019 dapat dilihat pada Tabel 6.

Producers Accuracy (PA) tertinggi diperoleh kelas Sawah, yaitu $100 \%$ dan sedangkan PA terendah ditunjukkan oleh kelas lahan terbuka, yaitu 66\%. Disisi lain kesalahan komisi tertinggi terdapat pada kelas Hutan dan Lahan Terbuka, yaitu 32\%. Hal ini menunjukkan bahwa pengambilan training area untuk kedua kelas tersebut melebar sehingga piksel yang harusnya bukan masuk ke dalam kedua kelas tersebut diambil alih sebagai kedua kelas tersebut. Sementara itu, kisaran training area pada kelas sawah adalah terbaik yang ditunjukkan oleh nilai kesalahan komisi terkecil 0\%. Untuk Users Accuracy, nilai tertinggi ditunjukkan oleh kelas sawah dan lahan terbuka yaitu $100 \%$, sedangkan nilai terendah ditampilkan oleh kelas semak yaitu $69 \%$. Kesalahan omisi terbesar pada penelitian ini diperoleh oleh kelas Semak, yaitu 33\%. Ini berarti pada beberapa piksel yang seharusnya menunjukkan kelas semak tidak digunakan sebagai training area. Sementara itu, kelas sawah dan lahan terbuka menunjukkan kesalahan omisi terkecil, yaitu 0\%. Pada penelitian ini untuk Overall Accuracy adalah $90 \%$. Nilai akurasi ketelitian ini cukup tinggi dan memenuhi syarat yang ditetapkan oleh USGS yang menyatakan tingkat ketelitian klasifikasi atau interpretasi dengan menggunakan penginderaan jauh minimum $85 \%$ (USGS, 2019). Dengan demikian ketelitian klasifikasi citra Landsat 8 di daerah penelitian dapat digunakan untuk perubahan penggunaan lahan.

Penelitian dengan citra yang serupa juga pernah di lakukan oleh Pryor (2012) di Alverta Utara, Canada.Dalam uji akurasi terhadap hasil klasifikasi 7 kelas tutupan lahan secara terbimbing menggunakan 3 data citra satelit yaitu Sentinel-2 MSI, landsat 5 TM dan SPOT 5 HRV dengan hasil Overall Accuracy masing - masing 90,4\%, 86,2\%, 80,6\%. Nurul Adhim (2017) juga melakukan uji akurasi terhadap 7 kelas tutupan lahan di daerah pesisir Kabupaten Lamongan dengan citra satelit yaitu citra Sentinel -2 MSI dan Landsat 8 OLI dengan masing-masing nilai Overall Accuracy $95 \%$ dan $86 \%$.

\section{Kesimpulan}

Adapun kesimpulan dari penelitian ini adalah sebagai berikut:

1. Hasil penggunaan lahan di daerah penelitian menggunakan citra satelit Landsat pada tahun 2002 dan 2019 adalah hutan, semak, sawah, perkebunan, lahan terbuka, pemukiman dan bangunan, serta perairan. Penggunaan lahan pemukiman dan bangunan menempati kelas yang terluas, yaitu 328.05 ha di tahun 2002 dan 565.74 ha di tahun 2019.

2. Selama kurun waktu 17 tahun (2002 - 2019). Kelas pemukiman dan bangunan mengalami peningkatan seluas 237.51 ha. Sementara penggunaan lahan Hutan, Semak, Sawah, Perkebunan, Lahan Terbuka, Perairan mengalami penurunan masing-masing 60.93 ha, 71.91 ha, 32.4 ha, 46.44 ha, 20.79 ha, dan 5.04 ha. Hal ini membuktikan bahwa dengan adanya perkembangan sektor pariwasata di daerah penelitian cukup banyak mengkonversi lahan bervegetasi menjadi pemukiman dan bangunan.

3. Overall Accuracy dari hasil klasifikasi penggunaan lahan didapatkan $90 \%$ dengan Producers Accuracy tertinggi sawah yaitu $100 \%$ diikuti oleh pemukiman dan bangunan $97 \%$, perairan $92 \%$, semak dan perkebunan masing-masing $71 \%$, serta terendah kelas hutan dan lahan terbuka $68 \%$. Sementara User Accuracy tertinggi ditunjukkan oleh kelas sawah dan lahan terbuka masing-masing $100 \%$ diikuti oleh pemukiman dan bangunan $92 \%$, hutan $87 \%$, perkebunan $80 \%$, perairan $73 \%$ dan yang terendah $67 \%$ pada kelas semak. 


\section{Daftar Pustaka.}

[BPS] Badan Pusat Statistik Kabupaten Lombok Barat. 2019. Batulayar Dalam Angka.2019. https://lombokbaratkab.bps.go.id/publication/2018/09/26/921024ffb04 c43c11bbe3ce3/kecamatan-batu-layar-dalam-angka-2018.html $\quad[14$ Oktober 2019]

[LAPAN] Lembaga Penerbangan dan Antariksa Nasional. 2014. Penyusunan Pedoman Pengolahan Digital Klasikasi Penutupan Lahan Menggunakan Penginderaan Jauh. http://pusfatja.lapan.go.id/files_uploads_ebook/publikasi/Buku\%20La poran\%202014\%20Final/000_Pedoman_final.pdf [14 Oktober 2019]

Asyiawati. 2010. Analisis Status Ekosistem Pesisir bagi Penyusunan Rencana Tata Ruang Wilayah Pesisir di Kawasan Teluk Kota Ambon: [Disertasi] Institut Pertanian Bogor

Chua T.E. 2006. The Dynamic of Integrated Coastal Management: Practical Applications in the Sustainable Coastal Development in East Asia. Global Environment Facility/UNDP/PEMSEA. Quezone City. HIm 468

Dahuri R, Rais J, Ginting SP, Sitepu MJ. 2013. Pengelolaan sumberdaya wilayah pesisir dan lautan secara terpadu. Jakarta (ID): Balai Pustaka.

Damai, AA. 2003. Pendekatan Sistem untuk Penataan Ruang Pesisir Kota Bandar Lampung. [Disertasi]. Program Pasca Sarjana. IPB. Bogor.

Darmawan, H. 2016. Rencana Pengelolaan Pesisir (Intergrated Coastal Management-ICM) Desa Batulayar Barat. $30 \mathrm{hlm}$

Hartono. 2010. Penginderaan Jauh Dan Sistem Informasi Geografi Serta Aplikasinya Di Bidang Pendidikan Dan Pembangunan. Seminar Nasional-PJ dan SIG I.

Herdiatma M, Ibnu P, Retno H. 2014. Evaluasi Perubahan Penggunaan Lahan Pesisir Kecamatan Tamalate Kota Makassar Menggunakan Citra Satelit Landsat 7 ETM+ Multitemporal Tahun 2006 - 2012. Journal Of Marine Research: 182-193

Nuarsa, I.W. 1998. Penggunaan Analisis Citra Digital Dan Sistem Informasi Geografi Untuk Prediksi Besarnya Erosi Di Das Ayung Bagian Hilir Kabupaten Badung Provinsi Bali [Tesis]. Yogyakarta: Program Pasca Sarjana, Universitas Gadjah Mada. 138 hal.

Pryor, LS. 2012. Land-Cover Mapping in an Agriculture Zone Using Simulated Sentinel-2 Data. Departement of Geography, Universty of Lethbridge Alberta. Canda

Schreuder HT, Ernst RL, Ramirez-Maldonado H. 2004. Statistical techniques for sampling and monitoring natural resources. US Departement of Agriculture, Forest Service, Rocky Mountain Research Station. $111 \mathrm{hlm}$.

Setiono B. 2006. Deteksi Perubahan Penutupan Lahan Menggunakan Citra Satelit Landsat Etm+ Di Daerah Aliran Sungai (Das) Juwana. Jawa Tengah [Skripsi]. Bogor: Fakultas Kehutanan, Institut Pertanian Bogor. $58 \mathrm{hlm}$ 